\title{
PENGARUH PENGETAHUAN DAN KEAGAMAAN TERHADAP SIKAP YANG MEMPENGARUHI MINAT PEMBELIAN KONSUMEN MUSLIM PADA KOSMETIK HALAL DI JABODETABEK
}

\author{
Marcellita Oktaviani \\ Program Studi Magister Manajemen Universitas Tarumanagara \\ marcellita.o@gmail.com \\ Hetty Karunia Tunjungsari \\ Program Studi Magister Manajemen Universitas Tarumanagara \\ Masuk : 04-06-2020, revisi : 25-06-2020 diterima untuk diterbitkan : 25-06-2020
}

\begin{abstract}
The purpose of this study is to examine whether 1) knowledge and religiosity affect the attitude of purchasing halal cosmetics, 2) knowledge and religiosity have a positive significant effect on the purchase intention of halal cosmetics, 3) attitudes mediate the affect between knowledge and religiosity on the purchase intention of halal cosmetics, 4) there are significant differences between attitudes and purchase intention of halal cosmetics and halal food. The unit of analysis of this study is the Muslim community that uses cosmetics and domiciled in JABODETABEK. Data was collected through a survey using a questionnaire. The respondents amounted to 200 respondents were selected by purposive sampling method. The data processing method used was PLS which processed through smartPLS 3.0 software. The results showed that 1) knowledge does not have a significant effect on attitudes and purchase intention of halal cosmetics, 2) religiosity has a significant effect on attitudes and purchase intention of halal cosmetics, 3) attitudes have a significant effect on purchase intention, and 4) attitudes mediate the effect between religiosity and the purchase intention of halal cosmetics. But it does not mediate between knowledge and purchase intention of halal cosmetics. 5) there are significant differences between attitudes and purchase intention of halal cosmetics and halal food.
\end{abstract}

Abstrak: Penelitian ini mempunyai tujuan untuk menguji apakah 1) pengetahuan dan keagamaan mempengaruhi sikap pembelian kosmetik halal, 2) pengetahuan dan keagamaan memiliki pengaruh positif signifikan terhadap minat pembelian kosmetik halal, 3) sikap memediasi pengaruh antara pengetahuan dan keagamaan terhadap minat pembelian kosmetik halal, 4) terdapat perbedaan yang signifikan antara sikap dan minat pembelian kosmetik halal dan makanan halal. Unit analis penelitian ini adalah masyarakat beragama Islam yang menggunakan kosmetik dan berdomisili di JABODETABEK. Data didapatkan melalui survei dengan menggunakan kuesioner. Responden yang didapatkan adalah 200 responden dengan teknik purposive sampling. Metode pengolahan data menggunakan PLS yang diproses melalui software smartPLS 3.0. Dari hasil penelitian ditunjukkan bahwa 1) pengetahuan tidak memiliki pengaruh signifikan terhadap sikap dan minat pembelian kosmetik halal dan keagamaan memiliki pengaruh signfikan terhadap sikap dan minat pembelian kosmetik halal. 2) sikap memiliki pengaruh signifikan terhadap minat pembelian, 3) sikap memediasi pengaruh antara keagamaan dengan minat pembelian kosmetik halal. Namun tidak memediasi antara pengetahuan dengan minat pembelian kosmetik halal. 4) terdapat perbedaan yang signifikan antara sikap dan minat pembelian kosmetik halal dan makanan halal.

Keywords: Pengetahuan, Keagamaan, Sikap, Minat Pembelian 


\section{PENDAHULUAN}

Pada saat ini produk halal semakin berkembang pesat di negara Asia, contohnya Arab Saudi dan Malaysia. Tetapi sayangnya, industri makanan dan kosmetik halal di Indonesia tidak berada di posisi top ten berdasarkan GIEI (Salaamgateaway.com). Padahal negara Indonesia memiliki resources demografi yang besar dimana $87.18 \%$ dari 237.641 .326 juta total populasi nasional adalah umat Muslim. Untuk dapat mengetahui masalah ini maka kita harus mencari tahu terlebih dahulu apa yang menjadi faktor-faktor dari kurang berkembangnya bisnis produk halal di Indonesia. Menurut Bergeaud-Blackler (2004) \& Golnaz et al. (2010) sebagaimana dikutip dari Wilkins et al. (2019) konsumen muslim dan non-muslim dapat mempertimbangkan kehalalan sebagai kualitas suatu produk makanan, dalam penelitian yang terkait tetapi berbeda, logis untuk menganggap bahwa konsumen yang menilai produk halal pasti akan lebih memilih mengkonsumsi makanan halal. Sikap yang dapat meningkatkan minat pembelian produk halal terhadap konsumen dapat dipengaruhi oleh pengetahuan dan keagamaan seseorang.

Menurut Che Ahmat et al. (2011) pengetahuan adalah keahlian dan keterampilan yang diperoleh seseorang atau sekelompok orang melalui pemahaman teoritis maupun praktik mengenai suatu subjek. Menurut Aertsens et al. (2011) juga pengetahuan memiliki pengaruh terhadap sikap yang dapat mempengaruhi minat pembelian seseorang. Selain pengetahuan yang mempengaruhi sikap terhadap minat pembelian, ada juga keagamaan yang dapat mempengaruhi minat pembelian produk halal. Menurut Johnson et al. (2011) keagamaan adalah sejauh mana seorang individu berkomitmen pada agamanya dan agama itu tercermin dalam sikap dan perilaku individual tersebut.

\section{TELAAH KEPUSTAKAAN}

Berdasarkan TRA, minat perilaku dinyatakan sebagai anteseden langsung dari perilaku dan merupakan hasil dari kombinasi sikap terhadap perilaku, yang didefinisikan sebagai perasaan umum seseorang akan kesukaan atau ketidakberuntungan untuk perilaku itu (Ajzen dan Fishbein, 1980). Berbagai studi terkait masalah ini telah dilakukan oleh beberapa peneliti. Berdasarkan TRA, minat perilaku dinyatakan sebagai anteseden langsung dari perilaku dan merupakan hasil dari kombinasi sikap terhadap perilaku, yang didefinisikan sebagai perasaan umum seseorang akan kesukaan atau ketidakberuntungan untuk perilaku itu (Ajzen dan Fishbein, 1980). Dalam studi yang lalu, disebutkan bahwa haram dan halal merupakan hukum yang wajib dipatuhi oleh umat muslim, oleh karena itu dalam konteks kosmetik halal maka akan dicari tahu hal yang mempengaruhi minat pembelian umat muslim. Pengetahuan memiliki pengaruh terhadap minat pembelian produk halal karena disebutkan bahwa keharusan muslim mengkonsumsi makanan halal termasuk makanan yang sifat dan teknik pengolahan. penanganan dari awal hingga akhir juga harus selalu disetujui oleh hukum Islam (Abdul, et al., 2009 dan Erdem, et al., 2015 dalam Nurhayati T. \& Hendar H., 2019). Oleh karena itu pengetahuan akan produk halal menjadi satu kesatuan bagian dari konsumen muslim dalam membuat keputusan dan munculnya minat untuk membeli produk halal.

Istilah halal sangat terkait dengan keagamaan umat muslim, karena itu tingkat keagamaan sangat penting sebagai penentu perilaku seseorang dalam mengkonsumsi makanan halal. Keagamaan adalah faktor yang sangat penting untuk minat pembelian produk halal menurut Awan, et al. (2015) sebagaimana dikutip dari Nurhayati T. \& Hendar H. (2019). Umumnya juga orang yang memiliki tingkat keagamaan yang tinggi akan memilih membeli makanan halal dan menahan diri agak tidak terlibat dalam kegiatan yang bertentangan dengan pedoman agama (Schneider et al.,2011 sebagaimana dikutip dari Nurhayati T. \& Hendar H., 2019).

Pada perbedaan untuk sikap dan minat pembelian terhadap kosmetik halal dan makanan halal, terdapat sebuah survei penelitian terhadap konsumen di UEA dan Arab Saudi yang menemukan bahwa konsumen pada umumnya mempertimbangkan kehalalan dalam hal daging (Irlandia dan Rajabzadeh, 2011). Irlandia dan Rajabzadeh (2011) menemukan bahwa beberapa konsumen di UAE juga mengkhawatirkan Meskipun halalitas produk lain, seperti 
perlengkapan mandi, hasil penelitian lain di Internet. Konsumen UEA (Rajagopal et al., 2011 sebagaimana dikutip dari Abd. Rahman, 2019) menunjukkan bahwa sebagian besar konsumen tidak pernah mencari halal sertifikasi ketika membeli produk kosmetik, kemungkinan karena mereka mengasosiasikan dengan halal hanya untuk konsumsi internal.

\section{Hipotesis Penelitian}

H1: Terdapat pengaruh positif signifikan antara pengetahuan dan minat pembelian terhadap kosmestik halal.

$\mathrm{H} 2$ : Terdapat pengaruh positif signifikan antara keagamaan dan minat pembelian terhadap kosmestik halal.

H3: Terdapat pengaruh positif signifikan antara pengetahuan dan sikap terhadap kosmetik halal.

H4: Terdapat pengaruh positif signifikan antara keagamaan dan sikap terhadap kosmetik halal.

H5: Terdapat pengaruh positif signifikan antara sikap terhadap produk kosmetik halal dan minat pembelian produk kosmetik halal.

H6: Sikap memediasi antara pengetahuan dan minat pembelian terhadap kosmetik halal.

H7: Sikap memediasi antara keagamaan dan minat pembelian terhadap kosmetik halal.

H8: Terdapat perbedaan yang signifikan antara sikap terhadap produk makanan halal dan sikap terhadap produk makanan halal.

H9: Terdapat perbedaan yang signifikan antara minat pembelian produk kosmetik halal dan minat pembelian produk makanan halal.

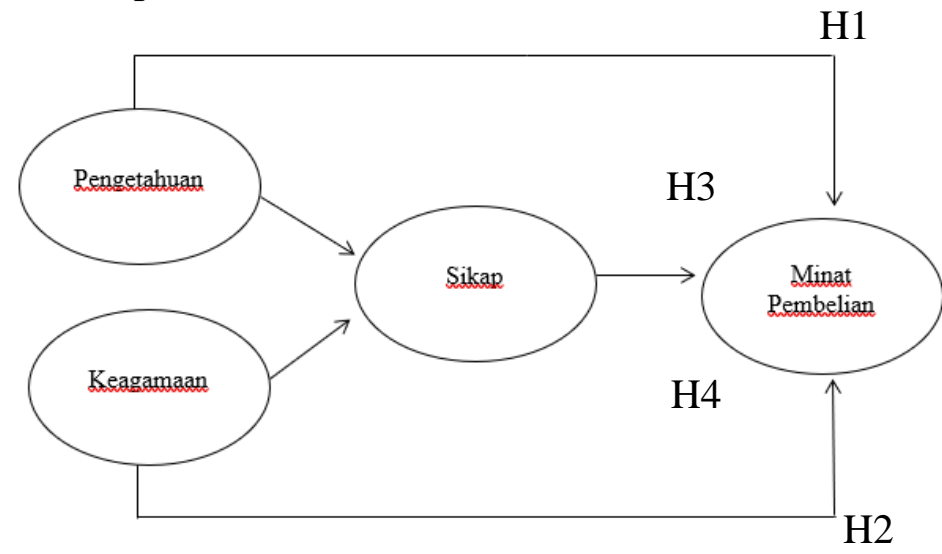

H5

Gambar 1

Model Penelitian

\section{METODOLOGI PENELITIAN}

Desain penelitian yang digunakan adalah penelitian deskriptif dengan metode cross sectional design. Penelitian ini merupakan penelitian kuantitatif. Sampel populasi dalam penelitian ini ialah konsumen muslim yang menggunakan kosmetik (seperti bedak, pemerah bibir, dan termasuk skincare) dan berdomisili di JABODETABEK. Sampel dalam penelitian ini sebanyak 200 responden. Data dikumpulkan melalui survei dengan menggunakan kuesioner online (google form). Teknik pemilihan sampel menggunakan purposive sampling. Pengukuran objek penelitian diukur menggunakan skala likert 5 poin, 1 menunjukkan "sangat tidak setuju" dan 5 menunjukkan "sangat setuju".

Metode analisis yang digunakan dalam penelitiain ini adalah Partial Least Square (PLS) yang diolah dengan menggunakan software SmartPLS 3.0. Ghozali \& Latan (2015) mengungkapan analisis PLS biasanya terdiri dari dua sub model yaitu outer model dan inner model. Langkah selanjutnya adalah dengan menguji GoF dan analisa mediasi, dan menguji paired sample T-test antara sikap dan minat pembelian kosmetik halal dan makanan halal dengan menggunakan SPSS. 


\section{HASIL DAN PEMBAHASAN}

Tidak terdapat pengaruh signifikan pengetahuan terhadap minat pembelian kosmetik halal. Hasil penelitian ini tidak memiliki hasil yang sama dengan penelitian yang dilakukan oleh Nurhayati T. \& Hendar H., 2019, tetapi sama dengan hasil penelitian yang dilakukan oleh Mohd Yusoff et al., (2015), yang dimana penelitian ini tentang ritel halal, pakan ternak halal, dan logistik halal tampaknya tidak menjadi prediktor penting dari minat konsumen untuk membeli produk halal. Studi ini dilakukan pada produk makanan, bukan pada produk kosmetik oleh karena itu, tidak seperti pandangan tentang makanan halal yang cenderung serupa di negara-negara Muslim, sikap terhadap kosmetik sangat bervariasi. Meskipun tidak memiliki sertifikasi halal, beberapa perusahaan kosmetik dan perawatan tubuh yang membanggakan bahan-bahan alami dalam upaya pemasaran mereka telah berhasil menarik konsumen beragama Islam, karena bahan-bahan tersebut sejalan dengan nilai Muslim (Patton, 2009 sebagaimana dikutip dari Mohd Yusoff et al., 2015). Hasil ini dapat memberikan beberapa penjelasan mengapa makanan memiliki kontribusi atas sebagian besar penjualan produk halal dibandingkan dengan kosmetik. Hal ini berarti perlunya lebih meningkatkan lagi pengetahuan masyarakat terhadap penjelasan mengenai halal.

Pengaruh positif dan signifikan keagamaan terhadap minat pembelian kosmetik halal. Hasil penelitian ini sejalan dengan Nurhayati T. \& Hendar H. (2019) bahwa apabila konsumen muslim yang memiliki tingkat keagamaan yang tinggi akan mencari produk halal bukan hanya makanan halal saja.

Pengaruh tidak signifikan pengetahuan terhadap sikap konsumen muslim tidak sejalan dengan penelitian yang dilakukan oleh Aertsens, et al. (2011), tetapi sejalan dengan penelitian yang dilakukan oleh Abd. Rahman, et al. (2019) yang menyatakan bahwa pengetahuan tidak mempengaruhi sikap. Penelitian yang sejalan dengan penelitian Abd. Rahman, et al. (2019) adalalah keagamaan mempunyai pengaruh yang signifikan terhadap sikap konsumen muslim yang bisa disebabkan dari tingginya tingkat keagamaan para konsumen muslim di JABODETABEK dan sikap juga memiliki pengaruh yang signifikan terhadap minat pembelian kosmetik halal.

Sikap juga tidak memediasi pengetahuan terhadap minat pembelian tetapi sikap memediasi keagamaan terhadap minat pembelian, penelitian ini sejalan dengan Abd. Rahman, et al. (2019).

Tabel 1

Hasil Uji Hipotesis

\begin{tabular}{|l|c|c|c|}
\hline Variabel & $\begin{array}{c}\text { Path } \\
\text { Coefficients }\end{array}$ & $\begin{array}{c}T \\
\text { Statistics }\end{array}$ & $\begin{array}{c}P \\
\text { Values }\end{array}$ \\
\hline Keagamaan $\rightarrow$ Minat Pembelian (Kosmetik Halal) & 0.215 & 3.957 & 0.000 \\
\hline Keagamaan $\rightarrow$ Sikap (Kosmetik Halal) & 0.61 & 12.676 & 0.000 \\
\hline Pengetahuan $\rightarrow$ Minat Pembelian (Kosmetik Halal) & -0.046 & 0.946 & 0.344 \\
\hline Pengetahuan $\rightarrow$ Sikap (Kosmetik Halal) & 0.13 & 1.837 & 0.066 \\
\hline Sikap (Kosmetik Halal) $\rightarrow$ Minat Pembelian (Kosmetik Halal) & 0.697 & 14.718 & 0.000 \\
\hline Keagamaan $\rightarrow$ Sikap (Kosmetik Halal) $\rightarrow$ Minat Pembelian (Kosmetik Halal) & 0.425 & 9.938 & 0.000 \\
\hline Pengetahuan $\rightarrow$ Sikap (Kosmetik Halal) $\rightarrow$ Minat Pembelian (Kosmetik Halal) & 0.09 & 1.776 & 0.076 \\
\hline
\end{tabular}

Berdasarkan hasil paired sample test dengan menggunakan SPSS, dapat dilihat hasil yang disajikan di tabel 2 yang memperlihatkan bahwa adanya perbedaan yang signifikan antara sikap terhadap kosmetik halal dan sikap terhadap makanan halal $(\mathrm{t}=-15.191, \mathrm{p}=0.000)$ dan juga terdapat perbedaan yang signifikan antara minat pembelian terhadap kosmetik halal dan minat pembelian terhadap makanan halal $(\mathrm{t}=-15.030, \mathrm{p}=0.000)$. Dan juga berdasarkan hasil di atas dapat dilihat bahwa konsumen muslim di JABODETABEK lebih mempunyai sikap positif terhadap minat pembelian makanan halal dibandingkan dengan kosmetik halal karena mayoritas konsumen muslim lebih peduli terhadap produk halal yang masuk ke dalam tubuh dibandingkan dengan yang tidak. Hasil penelitian ini didukung oleh Abd. Rahman, et al. (2019). 
Tabel 2

Hasil Paired Sample Test

\begin{tabular}{|l|c|c|}
\hline Pairs & $\mathrm{t}$ & Significance (2-tailed) \\
\hline Sikap (Kosmetik halal) - Sikap (Makanan halal) & -15.191 & 0.000 \\
\hline Minat Pembelian (Kosmetik halal) - Minat Pembelian (Makanan halal) & -15.03 & 0.000 \\
\hline
\end{tabular}

\section{KESIMPULAN}

Berdasarkan hasil analisa yang telah dibahas di atas, kesimpulan yang dapat diambil dari penelitian ini adalah (1) pengetahuan tidak memiliki pengaruh positif signifikan terhadap minat pembelian kosmetik halal, (2) pengetahuan tidak memiliki pengaruh positif signifikan terhadap sikap konsumen muslim pada kosmetik halal, (3) keagamaan memiliki pengaruh positif signifikan terhadap minat pembelian makanan halal, (4) keagamaan memiliki pengaruh positif signifikan terhadap sikap konsumen muslim pada kosmetik halal, (5) sikap konsumen muslim memiliki pengaruh positif signifikan terhadap minat pembelian kosmetik halal, (6) sikap konsumen muslim tidak memediasi pengaruh antara pengetahuan dengan minat pembelian kosmetik halal, (7) sikap konsumen muslim memediasi pengaruh antara keagamaan dengan minat pembelian kosmetik halal, (8 dan 9) terdapat perbedaan yang signifikan antara sikap dan minat pembelian terhadap kosmetik halal dan makanan halal. Saran dari penulis adalah beberapa brand kosmetik halal sebaiknya lebih menekankan terhadap kandungan dalam suatu produk di dalam kebanyakkan kosmetik yang beredar yang mengandung bahan tidak halal, pemasar juga dapat menggunakan cara yang sama dengan memasarkan makanan halal, seperti menggunakan bintang iklan yang memiliki image tinggi dalam keagamaan.

\section{DAFTAR PUSTAKA}

Abd Rahman, A., Asrarhaghighi, E., \& Ab Rahman, S. (2015). Consumers and halal cosmetic products: Knowledge, religiosity, attitude and intention. Journal of Islamic Marketing, 6(1), 148-163. doi:10.1108/jima-09-2013-0068

Aertsens, J., Mondelaers, K., Verbeke, W., Buysse, J., \& Van Huylenbroeck, G. (2011). The influence of subjective and objective knowledge on attitude, motivations and consumption of organic food. British Food Journal, 113(11), 1353-1378.

Ajzen, I., \& Fishbein, M. (1980). Understanding Attitudes and Predicting Social Behavior. NJ: Prentice-Hall.

Che Ahmat, N., Mohd Radzi, S., Zahari, M. S. M., Muhammad, R., Abdul Aziz, A., \& Ahmad, N. A. (2011). The effect of factors influencing the perception of price fairness towards customer response behaviors. Journal of Global Management, 2(1), 22.

Ghozali, I., \& Latan, H. (2015). Partial Least Squares Konsep, Teknik, dan Aplikasi Menggunakan Program SmartPLS 3.0 Untuk Penelitian Empiris (2 ${ }^{\text {nd }}$ ed.). Semarang, ID: Badan Penerbit Undip.

Johnson, B. R., Jang, S. J., Larson, D. B., De Li, S. (2001). Does adolescent religious commitment matter? Are examination of the effects of religiosity on delinquency. Journal of Research in Crime and Delinquency, 38(1), 22-44.

Mohd Yusoff, F. A., Raja Yusof, R. N., \& Hussin, S. R. (2015). Halal Food Supply Chain Knowledge and Purchase Intention.

Nurhayati, T., \& Hendar, H. (2019). Undefined. Journal of Islamic Marketing. doi:10.1108/jima-11-2018-0220

Salaamgateaway.com. (2018, June 17). An Inclusive Ethical Economy: State of the Global Islamic Economy Report 2018/19. Retrieved from https://haladinar.io/hdn/doc/report2018.pdf

Wilkins, S., Butt, M. M., Shams, F., \& Pérez, A. (2019). The acceptance of halal food in nonMuslim countries. Journal of Islamic Marketing, 10(4), 1308-1331. doi:10.1108/jima11-2017-0132 